\title{
Influence of Corporate Transparency Disclosures on Financial Performance of Listed Companies in East
}

\section{Africa}

\author{
Boniface Muriithi Wanjau (Corresponding author) \\ Department of Accounting, Finance and Economics, School of Business \\ Jomo Kenyatta University of Agriculture and Technology \\ E-mail: bmwanjau@gmail.com \\ Willy Mwangi Muturi \\ Department of Accounting, Finance and Economics, School of Business \\ Jomo Kenyatta University of Agriculture and Technology \\ Patrick Ngumi \\ Department of Accounting, Finance and Economics, School of Business \\ Jomo Kenyatta University of Agriculture and Technology
}

Received: Jan. 17, 2018 Accepted: Feb. 21, $2018 \quad$ Published: June 1, 2018

doi:10.5296/ajfa.v10i1.12492 URL: https://doi.org/10.5296/ajfa.v10i1.12492

\begin{abstract}
With the decline in the financial performance of listed companies in East Africa and the rising trend of corporate failure in both global and local perspective. Stakeholders are increasingly becoming more concerned of the financial performance of their firms. This study aimed to find out whether corporate transparency disclosure can be used to address the decline in financial performance and corporate failures. Therefore, the current study sought to examine the influence of corporate transparency disclosure on financial performance among companies listed in East Africa. Specifically, the study sought to examine the influence of
\end{abstract}




\section{Macrothink}

Asian Journal of Finance \& Accounting

ISSN 1946-052X 2018, Vol. 10, No. 1

financial transparency, risk transparency, social transparency and governance transparency on financial performance of companies listed in East Africa. The study adopted both descriptive and correlation design. Purposive sampling was used to select the 65 listed companies in Nairobi securities exchange in Kenya, 16 companies quoted in Uganda securities exchange, 7 companies which are quoted in Rwanda Securities Exchange as well as 24 companies listed in Daresalaam securities exchange from 2006 to 2015. Secondary data was collected through the use of document check index retrieved from annual audited financial statements. Regression diagnostic and panel data diagnostic tests were carried out. Results of the study revealed that there was a positive and significant relationship between financial, governance, risk, social transparency and financial performance of listed companies in East Africa.

Keywords: Financial Transparency, Social Transparency, Risk Transparency, Governance Transparency and Financial Performance 


\section{Introduction}

Transparency and disclosure are essential components of a robust corporate governance framework as they provide the base for informed decision making by shareholders, stakeholders and potential investors in relation to capital allocation, corporate transactions and financial performance monitoring. The importance of transparency has been widely recognized by both academics and market regulators, resulting in numerous rules and regulations being introduced over time to ensure timely and reliable disclosure of financial information, creating standards to which companies must adhere. Today, transparency is taking on a new meaning of more comprehensive and proactive disclosures instead of the release of corporate governance details or policies in a reactive fashion. The new concept of transparency putting more responsibilities in corporation not only let the truth be available to the public but imposes to disclose it to every stakeholder and different stakeholder groups (Fung, 2014).

Scholars of corporate governance give different definitions as legal systems, rules and historical development of different countries are also varied. Corporate governance is defined as the system by which business corporations are directed and controlled (Cadbury, 1992). Ruin (2001) defines corporate governance as a collective group of people united as one body with power and authority to direct, control and rule an organization. In this definition, group of people may mean all stakeholders of company. Craig (2005) stated that corporate governance is defined and practiced in different ways globally depending upon the relative power of owners, managers and provider of capital. It entails the procedures, customs, laws and policies that affect the way corporations are directed, administered or controlled.

An important objective of corporate governance is to ensure accountability and transparency for those who are involved in the policy implementation of organizations through mechanisms that will reduce principal agent conflict. Corporate governance is the system by which companies are directed and controlled. It specifies the distribution of rights and responsibilities among different participants in the corporation, such as the board, managers, shareholders and other stakeholders, and spells out the rules and procedures for making decisions on corporate affairs. It also provides the structure through which company objectives are set and monitoring performance attained (OECD, 1999).

The importance of transparency has been widely recognized by both academics and market regulators, resulting in numerous rules and regulations being introduced over time to ensure timely and reliable disclosure of financial information and creating standards to which companies must adhere. Transparency is taking on a new meaning of more comprehensive and proactive disclosures instead of the release of corporate governance details or policies in a reactive fashion. The new concept of transparency is putting more responsibilities on the corporation not only let the truth be available to the public but imposes to disclose it to every stakeholder and different stakeholder groups (Fung, 2014).

However, past studies on corporate governance and financial performance of listed firms have revealed scandals, collapse and frauds in major corporations like Enron, Tyco, WorldCom and Bank of Credit and Commerce International in the UK and US which has led 
to a lot of worldwide interest in issues of corporate governance. In East Africa listed firms questions have been raised on the governance since listed firms have been characterized with increased cases of corruption, mismanagement and government bailouts or subsidization on the failing enterprises like the Kenya Airways, Mumias Sugar Company in Kenya, Uchumi company limited in Kenya, Stanbic bank in Uganda and Tanzania had corruption related cases, just to name a few which has been in the media for all wrong reasons. This can be attributed to lack of transparency and inadequate disclosure of company results.

Huge efforts to revive the falling companies to profitability have focused on financial restructuring. However, managers and practitioners still lack adequate guidance for attaining optimal financing decisions (Kibet, Tenei \& Mutwol, 2011) as cited in Ayako (2012). This situation has led to loss of investors' wealth and confidence in the stock market. Corporate transparency has not been addressed leading to re-collapse of companies like Uchumi, Mumias sugar, Kenya airways, Eveready and National bank in Kenya. State reports reveal that low financial performances of listed companies is a major hindrance of the realization of vision 2030 leading to lower economic development and loss of jobs in Kenya and East Africa.

The current study sought to examine the influence of corporate transparency on financial performance of listed companies in East Africa. Specifically, the study sought to:

i. To examine the influence of financial transparency on financial performance in companies listed in East Africa.

ii. To establish the influence of risk transparency on financial performance in companies listed in East Africa.

iii. To establish the influence of governance transparency on financial performance in companies listed in East Africa.

iv. To find out the influence of social transparency on financial performance among companies listed in East Africa.

The hypotheses of the study were:

i. Ho: Financial transparency has no significant influence on financial performance among companies listed in East Africa securities exchanges.

ii. Ho: Risk transparency has no significant influence on financial performance among companies listed in East Africa securities exchanges.

iii. Ho: Governance transparency has no significant influence on financial performance among companies listed in East Africa securities exchanges.

iv. Ho: Social transparency has no significant influence on financial performance among companies listed in East Africa securities exchanges.

\section{Literature Review}

The genesis of corporate governance can be hinged on the agency theory which posits there 
exist a relationship between the agents and principles (Jensen \& Meckling, 1976). Currently there is principle agent relationship between the management of listed companies and shareholders who are the main contributors of capital. Mainly the study seeks to explain the relationship between corporate transparency disclosure and financial performance among companies listed in East Africa securities exchange. There are chances of information asymmetry between the shareholders and the choice of management who will be involved in the management of companies. A wise choice ought to be made as such to minimize the agency costs and save on monitoring costs which will trigger positive financial performance.

According to Jensen and Meckling (1976) there a positive and significant relationship between ownership control and agency conflicts since there are high chances of management pursuing their own self-interests at the expense of the shareholders. More so the attitude of management triggers the capital structure choice and if they are risk averse they may maintain lower gearing levels while risk seekers increases the financial risk. William, Ginter and Shewchuk (2006) argued that the primary purpose for studies on agency theory is to minimize the chances of information asymmetry. Similar studies such as Conyon and Schwalbach (2000) revealed positive relationship between corporate governance and elimination of agency costs. This precipitates the need for better corporate governance practices as such to eliminate the possibilities of information asymmetry.

In this study both shareholders and management have a relationship and those delegated with the day to day management of listed companies. The management should share the information which is important for decision making more so publicly shared information ought to be timely and accurate and reduce conflicts associated with investors' confidence.

Any good corporate governance system requires financial transparency as fundamental objectives of financial reporting. Making the management accountable of their action is an element of a good system with high level of disclosure. Tarus and Omandi (2013) conducted a study to examine business case for corporate transparency from Kenyan market. They hypothesized financial transparency to have a positive and significant effect on firm performance. Financial transparency was assessed using corporate disclosure index while firm performance was measured using the Return on Asset (ROA). Regression analysis supported the hypothesis of positive relationship though the correlation analysis showed this relationship to be weak.

A similar study by Ozbay (2009) was conducted to examine the relationship between corporate financial transparency and company performance in the Istanbul Stock Exchange (ISE) in Turkey. Secondary data for a total of 27 companies were sampled from annual reports for a period of 11years. These companies were selected since they were thought to be the largest and the most liquid companies in ISE. Company performance was assessed using market to book value (MTBV), price to cash flow (PTCF), price earnings ratio (PE) and market adjusted stock returns (MASR). Financial transparency was cross-checked with 36 attributes referring to accounting policies and standards, audit fees and efficiency indicators. Panel data analysis was applied and result of the finding showed that there was inverse relationship between MTBV, PTCF, MASR and financial transparency confirming Aksu and 
Kosedag (2006) findings. However, PE ratio showed a direct relationship with financial transparency.

Iatridis (2008) examined accounting disclosure and financial attributes in the UK market. Among the key accounting attributes is risk exposure disclosure. Firms ought to disclosure for assurance that they are still in line with the accounting regulation. Iatridis also argues that for a firm to raise capital in the debt markets an extensive risk disclosure is necessary since it improves companies' image as well as communicating to stakeholders how best manager are in managing risks.

Linsmeier, Thornton, Venkatachalam \& Welker (2002) in a study of the impact of risk disclosure on trading volume sensitivity to interest and exchange rate observed that stock prices and risk transparency have got a positive correlation. This can probably be explained due to shareholders being aware of the inherent risks and therefore coming up with mitigating mechanisms. According to stakeholder theory, companies with high degree risk should disclose the most amount of risk related information and explain the cause in an effort to reassure stakeholder that managers are prepared to address these risks (Abraham \& Cox, 2007).

Bhat, Hope and Kang (2006) investigated whether governance transparency affect forecasting accuracy by analyst. A sample of non-US firm cross-listed in the New York Stock Exchange as American Depositary Receipts was used covering period of 10 years. Governance transparency was found to be positively related to the accuracy of earning forecasts by analysts. Also, it's worth noting that governance transparency serves to explain forecasts when the financial transparency is low.

Stiglbauer (2010) investigated the transparency and disclosure of corporate governance in determining Germany companies' success. 100 Germany firms listed in the Prime Standard segment were sampled. Secondary data from compliance statement, annual report, compensation report, shareholder meetings, code of conduct and companies' websites were used. Firm performance was assessed using market to book value of equity and total shareholder return. Governance transparency and disclosure was indicated by disclosure index prepared as per the Germany regulation. It was established that there exists a significant positive relationship between corporate governance transparency and disclosure with firm performance using content analysis.

MolenKamp (2005) in a survey by KPMG discussed the social transparency benefits. It was seen that innovation, customized to help the stakeholders and enhanced corporate relationship made firm to enjoy long term benefits. A firm that engage in corporate social responsibility and discloses the same in their reports they are deemed to raise the esteem of the firms. Such firms are found to have a competitive advantage over other firms as they are considered to be social, friendly and thus the firms will able to meet their long term and short-term goals.

Tsoutsoura (2004) studied the impact of corporate social responsibility disclosure and financial performance of S\&P 500 firms for a period of five years. Financial performance was measured using accounting variables for profitability that is return on assets (ROA), return on 
equity (ROE) and return on sales (ROS) and social transparency was cross checked with the prepared list of corporate social indices. By applying regression for panel data, results indicated positive and significant relationships, confirming the view that social responsibility can be associated with a series of bottom line benefits. The choice of the regression analysis was inappropriate for a time series data and in this case panel data should have been analysed by time series or path analysis.

\section{Methodology}

\subsection{Research Design}

In the current study both descriptive and correlation research designs were applied. Kothari (2011) argued that through descriptive survey design the research seeks to describe the situation as it is. They were appropriate for the current study since the researcher seeks to describe the level of corporate transparency among companies listed in East Africa. Correlation design is used to explain the causal relationship between the dependent and independent variables (Oso \& Onen, 2009; Mugenda \& Mugenda, 2009; Kothari, 2011).

\subsection{Sample Size}

In the current study purposive sampling was used select companies which have been quoted for last 10 years in the east African stock exchanges among 51 companies which have been quoted in Nairobi securities exchange, 16 companies quoted in Uganda securities exchange, 7 companies which has been quoted in Rwanda Securities Exchange and 24 companies listed in Daresaalam securities exchange between 2006 to 2015. In total 80 listed companies were considered yielding $70 \%$ of the target population.

\subsection{Data Collection}

The study used secondary data drawn from financial report of listed firms. To collect data, the researcher will use the Nairobi Securities Exchange hand books and website, Uganda Securities Exchange website, Daresalaam Stock Exchange and Rwanda Stock Exchange website and companies' annual reports accessed through their offices. Where the researcher will not access the required information in the stated medium personally visited the specific company office. Therefore, the main data collection instrument for the secondary data was document disclosure check index on the specific study variables. Scoring approach was used on all the items as provided in the transparency index from which an overall score was calculated, if a company has provided the information it gets one (1) otherwise it will be awarded zero (0). Level of disclosure for every item will be calculated as:

Level of disclosure $=\underline{\text { Actual items disclosed }}$

Total possible items in the index

\subsection{Data Processing and Analysis}

The regression model used in the analysis will be as follows: 


$$
\text { Yit }=\beta_{0}+\beta_{1} X_{1 \text { it }}+\beta_{2} X_{2 i t}+\beta_{3} X_{3 i t}+\beta_{4} X_{4 i t}+\text { è it }
$$

Where; $Y_{\text {it }}$ represent financial performance

$\mathrm{X}_{1 \text { it }}$ represent financial transparency for firm $\mathrm{i}$ in period $\mathrm{t}$

$\mathrm{X}_{2 \mathrm{it}}$ represent Risk transparency for firm $\mathrm{i}$ in period $\mathrm{t}$

$\mathrm{X}_{3 \mathrm{it}}$ represent Governance transparency for firm $\mathrm{i}$ in period $\mathrm{t}$

$\mathrm{X}_{4 \mathrm{it}}$ represent Social transparency for firm $\mathrm{i}$ in period $\mathrm{t}$

\section{Findings and Discussions}

\subsection{Descriptive Statistics}

As shown in Table 4.1 the average return on asset was $9.9 \%$ with a minimum loss of $70 \%$ and maximum profit of $58 \%$. Further the distribution was skewed to the right since the skewness coefficient was 0.196 , the data was not normally distributed because the $p$ value for Jarque Berra was less than 0.05. Although, there were fluctuations on the return on investment as accounted for by standard deviation of 0.127 , the ventures were generally profitable and they gave returns to investors.

Concerning the level of financial transparency it averaged at $78 \%$, with a minimum of $1 \%$ and maximum of $100 \%$. A scrutiny in the normality of depicted that the financial transparency was not normally distributed since the $p$ value for Jarque Berra test was less than 0.05 . The data was skewed to the negative tail of the normal distribution. On average listed companies in East Africa voluntarily disclosed $52 \%$ of the risk related information with the highest companies elaborated on their risk exposure to the tune of $98 \%$. Thirdly, the average level of governance transparency was $66.4 \%$, with a minimum of $2 \%$ and a maximum of $98 \%$. The average disclosure of social transparency was $32 \%$ with a minimum of $3 \%$ and a maximum of $100 \%$. Social transparency was skewed to the right.

Table 4.1. Descriptive Statistics

\begin{tabular}{lccccc}
\hline & FP & FT & RT & GT & ST \\
\hline Mean & 0.099 & 0.776 & 0.520 & 0.664 & 0.319 \\
Median & 0.060 & 0.820 & 0.550 & 0.730 & 0.260 \\
Maximum & 0.580 & 1.000 & 0.980 & 0.970 & 1.000 \\
Minimum & -0.700 & 0.010 & 0.040 & 0.020 & 0.030 \\
Std. Dev. & 0.127 & 0.191 & 0.184 & 0.201 & 0.228 \\
Skewness & 0.196 & -2.336 & -0.782 & -1.113 & 1.759 \\
Kurtosis & 8.066 & 8.829 & 2.887 & 3.791 & 5.060 \\
Jarque-Bera & 785.264 & 1697.326 & 74.702 & 169.653 & 505.670 \\
Probability & 0.000 & 0.000 & 0.000 & 0.000 & 0.000 \\
\hline
\end{tabular}

*FP-Financial Performance, FT-Financial Transparency, RT-Risk Transparency, GT -Governance Transparency, ST- Social Transparency 


\subsection{Diagnostic Tests}

\subsubsection{Multicollinearity}

There was no multicollinearity since none of the correlation coefficient in absolute form was greater than 0.8, therefore there was no multicollinearity (Baltagi, 2005). According to El-Dereny and Rashwan (2011) VIF indicate how variance in the variables is inflated by multicollinearity. Hair, Ringle, and Sarstedt (2013) also states that a VIF larger than five indicate poor estimates.

Table 4.2. Multicollinearity

\begin{tabular}{lcc}
\hline & \multicolumn{2}{c}{ Collinearity Statistics } \\
& Tolerance & VIF \\
\hline Financial Transparency & 0.57 & 1.77 \\
Risk Transparency & 0.59 & 1.70 \\
Governance Transparency & 0.78 & 1.29 \\
Social Transparency & 0.90 & 1.12 \\
\hline
\end{tabular}

\subsubsection{Serial Autocorrelation}

Serial autocorrelation test was not significant and it signified absence of first order autocorrelation. Consistent with the early study of Ntim et al., (2012), serial correlation was found not to pose problem.

\subsubsection{Heteroskedasticity}

Further heteroscedasticity test was done by use Breusch-Pagan-Godfrey (Chi) test. According to Baltagi (2005) a good regression model should not have heteroscedasticity. Results in the study tested the null hypotheses that there was no heteroscedasticity for model, the test result yielded a chi-square value of 2.483 and $p$ value $>0.05$ in this case $p$ values was greater than 0.05 and not significant thus we did not reject the null hypotheses and concluded that heteroscedasticity was not present.

Table 4.3. Serial Autocorrelation and Heteroskedasticity

\begin{tabular}{lcc}
\hline Heteroskedasticity test & $\chi^{2}$-value & p-value \\
\hline Serial correlation & 2.483 & 0.065 \\
\hline & F-value & p-value \\
\hline
\end{tabular}

\subsubsection{Stationarity Tests}

As shown in Table 4.4, the null hypotheses that all panels had unit roots for all variables were rejected at 5\% level of significance since the $\mathrm{p}$ values were less than $5 \%$. This therefore implied that all variables were stationary and robust regression models would be fitted without lags (at levels). 
Table 4.4. Stationarity Tests

\begin{tabular}{llcc}
\hline & Method & Statistic & Prob.** \\
\hline FP & Levin, Lin \& Chu t* & -37.253 & 0.000 \\
& Im, Pesaran and Shin W-stat & -11.147 & 0.000 \\
& ADF - Fisher Chi-square & 273.374 & 0.000 \\
FT & PP - Fisher Chi-square & 307.054 & 0.000 \\
& Levin, Lin \& Chu t* & -14.264 & 0.000 \\
& Im, Pesaran and Shin W-stat & -7.330 & 0.000 \\
& ADF - Fisher Chi-square & 312.907 & 0.000 \\
RT & PP - Fisher Chi-square & 323.357 & 0.000 \\
& Levin, Lin \& Chu t* & -4.413 & 0.000 \\
& Im, Pesaran and Shin W-stat & -4.282 & 0.000 \\
& ADF - Fisher Chi-square & 227.853 & 0.000 \\
GT & PP - Fisher Chi-square & 168.060 & 0.002 \\
& Levin, Lin \& Chu t* & -15.389 & 0.000 \\
& Im, Pesaran and Shin W-stat & -8.070 & 0.000 \\
& ADF - Fisher Chi-square & 321.287 & 0.000 \\
ST & PP - Fisher Chi-square & 334.643 & 0.000 \\
& Levin, Lin \& Chu t* & -14.148 & 0.000 \\
& Im, Pesaran and Shin W-stat & -7.927 & 0.000 \\
& ADF - Fisher Chi-square & 329.803 & 0.000 \\
& PP - Fisher Chi-square & 363.908 & 0.000 \\
\hline
\end{tabular}

\subsubsection{Hausman Specifications}

As shown in Table 4.5 for models with and without moderations, the null was rejected at $5 \%$ level of significance since the $\mathrm{p}$ values were less than 0.05 . This implies that the most preferred models were fixed effects and this was in agreement with (Baltagi, 2005) who recommended it.

Table 4.5. Hausman Specifications

\begin{tabular}{lcccc}
\hline Test Summary & & Chi-Sq. Statistic & Chi-Sq. d.f. & Prob. \\
\hline & & 69.891 & 4 & 0.00 \\
\hline Variable & Fixed & Random & Var (Diff.) & Prob. \\
\hline FT & 0.170 & 0.167 & 0.000 & 0.5428 \\
RT & -0.008 & -0.011 & 0.000 & 0.3205 \\
GT & 0.080 & 0.085 & 0.000 & 0.1668 \\
ST & 0.245 & 0.286 & 0.000 & 0.00 \\
\hline
\end{tabular}

\subsection{Regression Analysis}

Results in Table 4.3 shows the full model of the study as conceptualized in the conceptual framework. As shown, the findings indicate an $\mathrm{R}$ squared of 0.763 , which indicates that $76.3 \%$ of the variation in financial performance can be explained jointly by financial transparency, risk transparency, governance transparency and social transparency while the 
remaining percentage can be accounted by other factors. An F-statistic of 27.657 with a $p$ value of 0.000 , indicate a joint significant contribution of the study variables.

There was a positive and significant relationship between financial transparency and financial performance $(\beta=0.170, \mathrm{p}$ value $<0.05$ ). This implies that while holding risk transparency, governance transparency and social transparency constant a unit change in financial transparency increases financial performance by 0.170 units. In line with this finding, Francis, Huang, Khurana and Pereira (2009) also established that financial transparency give the markets more considerations and that more information with regard to agency relationship tends to lower the agency cost which consequently translate to better firm performance.

Secondly, there was a positive and non-significant relationship between risk transparency and financial performance $(\beta=0.008, p$ value $<0.05)$. In tandem with Cebenoyan and Strahan (2004) the positive relationship could be as result of the articulation of the future risk profiles to affect the state of the capital structure thus developing the cost of capital. As per Tarus and Omandi (2013) when a firm encompasses way of diversifying the risk exposed, it actually tell more about the quality of the management which is later translated to more confidence being created to the investors.

Thirdly, there was a positive and significant relationship between governance transparency and financial performance $(\beta=0.08, \mathrm{p}$ value $<0.05)$. This implies that holding financial transparency, risk transparency and social transparency constant a unit change in governance transparency increases financial performance by 0.08 units. As argued by Donaldson (2003) disclosure on governance encourages corporate accountability which further builds business reputation and images on the faces of the interested parties and groups.

Finally, there was a positive and significant relationship between social transparency and financial performance $(\beta=0.245$, p value $<0.05)$. This implies that while holding financial transparency, risk transparency and governance transparency constant a unit change in social transparency increases financial performance by 0.245 units. The presumed insignificant relationship was confirmed to be actually false. As for the Molenkamp (2005) disclosure on social responsibility communicates the benefits received by stakeholders hence this disclosure tends to increase the connection between the firm and stakeholder. This further corroborates with stakeholder theory which avers that an attention to stakeholders will make a firm more successful than those that are not oriented to the need of the stakeholders.

Financial Performance $=-0.160+0.17 *$ Financial Transparency $+0.008 *$ Risk Transparency $+0.08 *$ Governance Transparency $+0.245 *$ Social Transparency 
Table 4.6. Regression Model of Influence for Corporate Transparency on Financial Performance of Listed Companies in East Africa

\begin{tabular}{lcccc}
\hline Variable & Coefficient & Std. Error & t-Statistic & Prob. \\
\hline C & -0.160 & 0.013 & -12.641 & 0.000 \\
Financial Transparency & 0.170 & 0.019 & 9.108 & 0.000 \\
Risk Transparency & 0.008 & 0.018 & 0.455 & 0.649 \\
Governance Transparency & 0.080 & 0.015 & 5.223 & 0.000 \\
Social Transparency & 0.245 & 0.014 & 17.706 & 0.000 \\
R-squared & 0.763 & Mean dependent variable & & 0.099 \\
Adjusted R-squared & 0.735 & S.D. dependent variable & 0.127 \\
S.E. of regression & 0.065 & Akaike info criterion & & -2.517 \\
Sum squared residuals & 2.792 & Schwarz criterion & & -2.033 \\
Log likelihood & 995.813 & Hannan-Quinn criterion. & -2.330 \\
F-statistic & 27.657 & Durbin-Watson stat & & 1.650 \\
Prob (F-statistic) & 0.000 & & & \\
\hline
\end{tabular}

\section{Summary and Conclusion}

Based on the study findings it is imperative to conclude that corporate transparency has effect on financial performance of listed companies in East Africa. Results of the study revealed that there was almost $80 \%$ of financial transparency, it can be implied that listed companies in East Africa are more willing to disclosure information to members of the public as such to mitigate agency conflicts and minimize the asymmetric information levels. Since there was a positive and significant relationship this implies as performance was increasing the level of transparency also increased within the period under investigation, it can therefore be concluded that an increased level of transparency enhanced financial performance and efficiency. Generally it's prudent for listed companies to disclose as much information as possible so as to minimize the level of information asymmetry and consequently stimulate financial performance.

Secondly, risk transparency mirrored the existing literature by having positive and significant relationship with financial performance. It can be concluded that risk transparency gives a yardstick against which future outlook of a specific organization can be evaluated and a clear strategy can developed in order to protect investor's interest. Indeed, a clear road map on future risk profile will provide a good credit evaluation tool and will impact the future capital composition within listed and non-listed companies. Therefore, it is imperative for the management to disclose risk exposure information as such to boost investor confidence and minimize issues related to low levels of information disclosure.

Thirdly, governance transparency had positive and significant relationship with financial performance. These findings were in conformity with theoretical stipulations since coherent governance principles should harmonize expectations of all stakeholders more so management and shareholders. Through this increased level of information sharing shareholders value is anticipated to increase because investors have a yardstick against which to monitor the management. Indeed, through this listed companies accountability and 
reputation are enhanced to rhyme with interest of both current and potential investors as well as debt providers. Because of enhanced level of governance there will be reduction in agency conflicts, boost of investor confidence and consequently enhanced financial performance.

Further, there was a positive and significant relationship between social transparency and financial performance of listed companies in East Africa. Therefore, it can be concluded that those firms which are consistently involved in corporate social responsibilities benefits from engaging stakeholders in other issues beyond normal lines of their business. Indeed, social activities increases company's reputation through social capital development and ultimately fosters financial performance. Thus, it can be concluded that engagement in social activities enhances stakeholders bonding and ultimately enhances performance.

The Kenya vision 2030 anticipates full access of capital for all investment needs; this can be achieved if many companies are listed. To achieve full benefits upon listing there is need for listed companies to share information freely to current and potential investors. This can only be achieved if companies adhere to provisions as stipulated by international financial reporting standards. The ability of listed companies to provide information freely will boost investor confidence and consequently attract both local and international investors.

To the East African securities exchanges as they endeavor to formation of a regional capital market there is need to foster on the need for listed companies to be as transparent as possible this will boost capital flight to local markets and ultimately promote investment culture and foster economic development.

Since all the four facets of corporate transparency had positive significant relationship there is need for more clear guidelines to be customized to enhance the level of transparency in every sector in which companies are listed. It will be paramount for the incumbent management of all listed companies to evaluate their levels of transparency and in areas where they are void they increase as such to minimize agency conflict.

To the East African community secretariat it is recommended that they lobby aggressively for regulatory and technological advancement which would enhance cross border listing and trading to be enacted and adopted by all East Africa Community (EAC) members swiftly. Moreover, the measures should be in tandem in enhancing corporate transparency and this will ultimately strengthen the growth of East Africa securities exchanges through coherent and streamlined networking platforms.

\subsection{Suggestions for Further Studies}

Since the current study drew respondents from East Africa for a period of ten years there is need for a similar study to be carried out in Africa, Europe, America or Asia. This will necessitate comparison of the study findings and minimize possibilities of generalizing the current findings. Secondly, there is need to carry out a study for each independent country securities market and considered other facets of corporate transparency disclosures beyond risk, social, financial and governance. 


\section{References}

Abraham, S \& Cox, P. (2007). Analyzing the Determinants of Narrative risk Information in UK FTSE 100 Annual Reports. The British Accounting Review, 39(3), 227-248. https://doi.org/10.1016/j.bar.2007.06.002

Aksu, M., \& Kosedag, A. (2005). The Relationship between Transparency \& Disclosure and Firm Performance in the ISE: Does IFRS Adoption Make a Difference? Available online on https://www.researchgate.net accessed on 23/1/2017.

Ayako, A., Kungu, G., \& Githui, T. (2012). Determinants of the Performance of Firms Listed at the Nairobi Securities Exchange. Research Journal of Finance and Accounting, 6(12), 157-164.

Baltagi, B.H. (2005). Econometric analysis of panel data, John Wiley \& sons

Bhat, G., Hope, O., \& Kang, T. (2006). Does corporate governance transparency affect the accuracy of analyst forecasts?. Journal of Accounting \& Finance, 46(5), 715-732. https://doi.org/10.1111/j.1467-629X.2006.00191.x

Cadbury, A. (1992). Codes of Best Practice, Report from the committee on Financial Aspects of Corporate Governance. London, Gee Publishing

Cebenoyan, A.S., \& Strahan, P.E. (2004). Risk Management, Capital Structure and Lending at $\begin{array}{lllll}\text { Banks. Journal of Banking \& } & \text { Finance, } & 2(8), 43 .\end{array}$ https://doi.org/10.1016/S0378-4266(02)00391-6

Conyon, M., \& Joachim S, (2000). Executive compensation: Evidence from the UK and Germany, Long Range Planning, 53, 504-526. https://doi.org/10.1016/S0024-6301(00)00052-2

Craig, V. V. (2005). The Changing Corporate Governance Environment: Implications for the Banking Industry. FDIC Banking Review, 4(2), 1-15.

Donaldson, W.H. (2003). Corporate governance. Business Economics, 3(8), 16-20.

El-Dereny, M., \& Rashwan, N. I. (2011). Solving Multicollinearity Problem Using Ridge Regression Models. International Journal of Contemporary Mathematical Sciences, 6(12), 585-600.

Francis, J.R., Huang, S., Khurana, I. K., \& Pereira, R. (2009). Does Corporate Transparency Contribute to Efficient Resource Allocation, Journal of Accounting Research, 47(4), 943-989. https://doi.org/10.1111/j.1475-679X.2009.00340.x

Fung, B. (2014). The Demand and Need for Transparency and Disclosure in Corporate Governance. Universal Journal of Management, 2(2), 72-80

Jensen, M. C., \& Meckling, W. H. (1976). Theory of the Firm: Managerial Behaviour, Agency Costs, and Ownership Structure. Journal of Financial Economics, 3(4), 305-350. https://doi.org/10.1016/0304-405X(76)90026-X 
Kibet, C. Y. (2015). Effect of Enterprise Risk Management Determinants on Financial Performance Management of Listed Companies in Nairobi Securities Exchange, Unpublished $\mathrm{PhD}$ thesis, Jomo Kenyatta University of Agriculture and Technology.

Kombo D., \& Tromp, D. (2006). Proposal and Thesis Writing, An Introduction. Nairobi: Pauline Publications Africa.

Kothari, C. R. (2011). Research Methodology. Methods and Techniques. New Age International Publishers. New Delhi. India.

KPMG. (2005). KPMG International Survey of Corporate Responsibility Reporting 2005, Accessed online on https://commdev.org on 24/6/2017.

Mugenda, O., \& Mugenda, V. (2009). Research Methods: Quantitative and Qualitative Approaches. Nairobi: ACTS

Ndili, W. M., \& Muturi, W., (2015). Does Financing Policy Decision Influence Firm Performance a Kenyan Perspective. International Journal of Education and Research, 3(10), $337-354$

Ntim, C. G., Opong, K. K., \& Danbolt, J. (2012). The Relative Value Relevance of Shareholder versus Stakeholder Corporate Governance Disclosure Policy Reforms in South Africa. An International Review, 20(1), 84-105. https://doi.org/10.1111/j.1467-8683.2011.00891.x

OECD (1999). OECD Principles of Corporate Governance, Accessed online on http://www.oecd.org on 24/6/2017.

Oso,Y. \& Onen, Y.(2009). Beginners guide to research and proposal writing (2 ${ }^{\text {nd }}$ Edition). Jomo Kenyatta Publishers. Nairobi. Kenya.

Ruin,J.E. (2001). Essentials of the corporate management; Kuala Lumpur, MICG

Sekaran, U., \& Bougie, R. (2013). Research Methods for Business (6 ${ }^{\text {th }}$ edition). John Wiley \& Sons Ltd

Tarus, D. K., \& Omandi, E. M. (2013). Business Case for Corporate Transparency: Evidence from Kenya. European Journal of Business and Management, 5(3), 113-125.

Tsoutsoura, M. (2004). Corporate Social Responsibility and Financial Performance. California: University of California at Berkeley. Accessed online: https:/www.dl.icdst.org at $23 / 5 / 2017$.

Wangechi, C. N., \& Nasieku, T. O. (2015). Relationship between Board Characteristics and Capital Structure among Companies Listed in East Africa. International Journal of Education and Research, 3(10), 355-372.

Williams, D. R., Duncan W. J., \& Ginter P. M. (2006). Structuring Deals and Governance after the IPO: Entrepreneurs and Venture Capitalists in High Tech Start-ups. Business Horizons, 4(9), 303-311. https://doi.org/10.1016/j.bushor.2005.11.001 